\title{
Predominant $D_{1}$ Receptors Involvement in the Over-expression of CART Peptides after Repeated Cocaine Administration
}

\author{
Zhenzhen $\mathrm{Hu}^{1}$, Eun-Hye $\mathrm{Oh}^{2}$, Yeon Bok Chung', Jin Tae $\mathrm{Hong}^{2}$, and $\mathrm{Ki}-\mathrm{Wan} \mathrm{Oh}^{2}$ \\ ${ }^{1}$ Department of Pathophysiology, College of Medicine, Nanchang University, Jiangxi 330006 China, ${ }^{2}$ Department of Pharmacy, College of \\ Pharmacy, Chungbuk National University, Cheongju 361-763, Korea
}

\begin{abstract}
The aim of this study was to investigate the involvement of dopaminergic receptors (DR) in behavioral sensitization, as measured by locomotor activity, and the over-expression of cocaine- and amphetamine-regulated transcript (CART) peptides after repeated administration of cocaine in mice. Repeated administrations of cocaine induced behavioral sensitization and CART over-expression in mice. The levels of striatal CART mRNA were significantly increased on the $3^{\text {rd }}$ day. CART peptides were over-expressed on the $5^{\text {th }}$ day in the striata of behaviorally sensitized mice. A higher proportion of $\mathrm{CART}^{+}$cells in the cocaine-treated mice were present in the nucleus accumbens (NAc) shell than in the dorsolateral (DL) part of caudate putamen (CP). The concomitant administration of both $D_{1} R$ and $D_{2} R$ antagonists, SCH $23390\left(D_{1} R\right.$ selective) and raclopride $\left(D_{2} R\right.$ selective), blocked cocaine inducedbehavioral sensitization, CART over-expression, and cyclic adenosine 5'-monophosphate (cAMP)/ protein kinase A (PKA)/phospho-cAMP response element-binding protein (pCREB) signal pathways. SCH 23390 more predominantly inhibited the locomotor activity, CART over-expression, $p$ CREB and PKA activity than raclopride. Cocaine induced-behavioral sensitization was also attenuated in the both $D_{1} R$ and $\mathrm{D}_{2} \mathrm{R}$ knockout (KO) mice, respectively. CART over-expression and activated cAMP/PKA/pCREB signal pathways were inhibited in the $D_{1} R-K O$ mice, but not in the $D_{2} R-K O$ mice. It is suggested that behavioral sensitization, CART over-expression and activated cAMP/PKA/pCREB signal pathways induced by repeated administration of cocaine could be more predominantly mediated by $D_{1} R$.
\end{abstract}

Key Words: cAMP, cAMP/PKA/pCREB signal pathways, CART, Cocaine, Dopamine receptors

\section{INTRODUCTION}

Repeated administration of cocaine elicits specific behaviors referred as sensitization, reward, reinforcement, and drug induced psychosis in animals and humans [1-5]. The striatonigral pathway (direct pathway) contains neurons with dynorphin, substance $\mathrm{P}$, and dopaminergic $\mathrm{D}_{1}$ receptors $\left(D_{1} R\right)$, whereas striatopallidal pathway (indirect pathway) preferentially contains neurons with enkephalin and dopamine $D_{2}$ receptors $\left(D_{2} R\right)$ [6]. $D_{1} R$ and $D_{2} R$ antagonists inhibited locomotor activity induced by psychostimulants $[7,8]$. However, the concomitant administration of $D_{1} R$ and $\mathrm{D}_{2} \mathrm{R}$ agonists enhances behavioral sensitization (BS) [9]. Cocaine did not increase locomotor activity in $\mathrm{D}_{1} \mathrm{R}$ knockout (KO) mice $[10,11]$. The locomotor response to cocaine was

Received September 18, 2014, Revised November 18, 2014, Accepted December 5, 2014

Corresponding to: Ki-Wan Oh, Department of Pharmacy, College of Pharmacy, Chungbuk National University, Seowon-gu, Cheongju 361-763, Korea. (Tel) 82-43-261-2827, (Fax) 82-43-268-2732, (E-mail) kiwan@ chungbuk.ac.kr

(i) (8) This is an Open Access article distributed under the terms of the Creative Commons Attribution Non-Commercial License (http:/ Creative Commons Atribution which permits unrestricted non-commercial creativecommons.orgicent reproduction in any medium, provided the original work attenuated in $\mathrm{D}_{2} \mathrm{R}$ KO mice [12].

Cocaine- and amphetamine-regulated transcript (CART) peptides that are highly expressed within the nucleus accumbens (NAc), hypothalamus, and ventral tegmental area (VTA) may contribute to drug reinforcement, rewarding-seeking behaviors, and addiction liability of psychostimulants $[13,14]$. CART mRNA was originally shown to be up-regulated in the rat striatum after acute cocaine or amphetamine administration [15]. Repeated administration of cocaine or amphetamine gradually reduced the level of over-expressed CART [16,17]. Direct injections of CART peptides55-102 into the $\mathrm{NC}$ attenuate both cocaine- and dopamine-induced locomotor activity [18]. $\mathrm{D}_{1}$ and $\mathrm{D}_{2} / \mathrm{D}_{3} \mathrm{R}$ antagonists inhibit the ethanol-induced over-expression of CART in the rat NC [19]. CART expression is regulated via adenylyl cyclase and cyclic adenosine 5'-monophosphate (cAMP)/protein kinase A (PKA)-mediating signaling, and likely through the activation of cAMP response element-binding protein (CREB) [20-22].

While both DRs and CART peptides contribute substantially to the development and/or expression of cocaine-induced behavioral sensitization, it remains unclear how the expression of CART peptides is mediated via both $D_{1} R$ and

ABBREVIATIONS: DR, dopaminergic receptors; CART, cocaine- and amphetamine-regulated transcript; NAc, nucleus accumbens; DL dorsolateral; CP, caudate putamen; cAMP, cyclic adenosine 5'-monophosphate; $\mathrm{PK}$, protein kinase A; $p$ CREB, phospho-cAMP response element-binding protein; NO, knockout. 
$\mathrm{D}_{2} \mathrm{R}$ in the development of cocaine-induced behavioral sensitization. In the present study, the mRNA expression of CART mRNA and distribution in the striatum of male C57BL/6 mice were assessed after repeated administration of cocaine. We investigated the involvement of $D_{1} R$ and $D_{2} R$ in the overexpression of CART peptides and cAMP/PKA $/ p$ CREB signaling pathways in the striata of behaviorally sensitized mice. The levels of CART peptides after repeated administration of cocaine were compared with those of both $D_{1} R$ and $\mathrm{D}_{2} \mathrm{R}$ - knockout $\left(\mathrm{D}_{1} \mathrm{R}\right.$ - and $\left.\mathrm{D}_{2} \mathrm{R}-\mathrm{KO}\right)$ mice, and wild type (WT) mice.

\section{METHODS}

\section{Materials}

Cocaine, $\mathrm{D}_{1} \mathrm{R}$ antagonist [R(+)-SCH-23390 hydrochloride] and $\mathrm{D}_{2} \mathrm{R}$ antagonist [S(-)-raclopride(+)-tartrate salt] were purchased from the Sigma Chemical Company (St. Louis, MO, USA). All chemicals were dissolved immediately in physiological saline before use. The CART and GAPDH primers, M-MLV reverse transcriptase and AccuPower PCR PreMix were purchased from Bioneer Co. (Seoul, Korea). The 2X SYBR Green Master Mix was purchased from Applied Biosystems (Carlsbad, CA, USA). The anti-CART and anti-GAPDH antibodies were purchased from Santa Cruz Biotechnology (Santa Cruz, CA, USA). The anti-phospho[Ser-133] CREB, anti- CREB, and anti-PKA antibodies were purchased from Abcam (Cambridge, MA, USA). The Vectastain ABC reagent was purchased from Vector Laboratories Co. (Burlingame, CA, USA). The Cyclic AMP XP ${ }^{\mathrm{TM}}$ Assay Kit was purchased from Cell Signaling Technology Inc. (Danvers, MA, USA). Protein G Sepharose 4 Fast Flow was purchased from GE Healthcare Bio- Sciences AB (Uppsala, Sweden). The PKA Assay kit was purchased from Millipore Co. (Bedford, MA, USA). The $\left[\gamma-{ }^{32} \mathrm{P}\right]$ ATP was purchased from Perkin Elmer, Inc. (Covina, CA, USA). All other materials were of the highest grade available and were obtained from normal commercial sources.

\section{Animals}

Adult male C57BL/6 mice weighing $25 \sim 30$ g were purchased from the Samtako Company (Osan, Korea). The adult heterozygous $D_{1} R-K O$ mice $\left(D_{1} R^{+l-}\right)$ were purchased from the RIKEN BioResource Center (Tsukuba, Japan). The mice were genotyped by PCR analysis of genomic DNA using standard PCR protocols (http://www2.brc.riken.jp/cache_all/RBRC01080, data not shown). The homozygous $\mathrm{D}_{2} \mathrm{R}-\mathrm{KO}$ mice $\left(\mathrm{D}_{2} \mathrm{R}^{-l-}\right)$ were purchased from the Jackson Laboratory (Bar Harbor, ME, USA). The mice were genotyped by PCR analysis of genomic DNA using the $\mathrm{JAX}^{\mathbb{B}}$ genotyping protocols (http://jaxmice.jax.org/ strain/003190.html, data not shown). Mice were housed with water and food available ad libitum under an artificial 12:12 $\mathrm{h}$ light/dark cycle (light at 07:00) and constant temperature $\left(22 \pm 2^{\circ} \mathrm{C}\right)$. All of the experiments using animals were performed in accordance with the National Institutes of Health Guide for the Care and Use of Laboratory Animals (NIH publication No. 85-23, revised 1985), and the Institutional Animal Care and Use Committee of Chungbuk National University approved the protocol.

\section{Measurement of locomotor activity}

All of the experiments were done in a randomized, bal- anced repeated-measures design, such that each mice received all of the treatments. A separate group of at least 8 mice were used for each experiments. The locomotor activity was measured using a tilting-type ambulometer (AMB-10, O'Hara, Tokyo, Japan). Each mouse was placed in an activity cage (20-cm diameter, $18-\mathrm{cm}$ height). The control mice were given saline subcutaneously under the same conditions. Cocaine was administered to mice once per day for 7 days. The mice were first allowed to perambulate for $10 \mathrm{~min}$ in the activity cages followed by a 1-h test period immediately after saline or cocaine administration. The development of behavioral sensitization after 5 or 7 days was evidenced by increased locomotor activity in response to cocaine, and compared with activity on the $1^{\text {st }}$ day [23]. In addition, to measure inhibitory effects of cocaine-induced hyperactivity, SCH $23390(0.25$ $\mathrm{mg} / \mathrm{kg})$ or raclopride $(0.4 \mathrm{mg} / \mathrm{kg})$ was pretreated intraperitoneally (i.p.) to mice, $25 \mathrm{~min}$ prior to cocaine administration once per day for 5 days [24]. Cocaine $(15 \mathrm{mg} / \mathrm{kg}$, s.c.) was also administered to the $\mathrm{D}_{1} \mathrm{R}$ - and $\mathrm{D}_{2} \mathrm{R}-\mathrm{KO}$ mice for once a day for 5 days.

\section{Real-time polymerase chain reaction (qRT-PCR) analysis}

The separate groups of 4 mice were sacrificed by decapitation $22 \mathrm{~h}$ after the administration of cocaine $(5,15$ and $30 \mathrm{mg} / \mathrm{kg}$, s.c.) for $3,5,7$ and 14 days, respectively. The total number of naimals is 48 mice. The striata including the NAc, were extracted at the coronal level at ${ }^{+} 1.6$ and ${ }^{+} 1.0 \mathrm{~mm}$ from the bregma, according to the stereotaxic atlas [25]. The CART mRNA levels in the striata were quantified using qRT-PCR. The sequences for the primers and an internal control for CART were designed in accordance with a previously published paper (CART: forward primer: CGAGAAGAAGTACGGCCAAG; reverse primer: GGAATATGGGAACCGAAGGT; GAPDH: forward primer: AAATTCAACGGCACAGTCAA; reverse primer: GAACGGACGGAGATGATGAC) [26]. The total RNA was extracted using TRIzol reagent. The reverse transcription reaction using M-MLV reverse transcriptase was performed according to the manufacturer's instructions. The qRT-PCR was performed using a 7,500 detection system (Applied Biosystems, Carlsbad, CA, USA). The reaction was conducted in a $20-\mu 1$ reaction mixture containing 2X SYBR Green Master Mix, $250 \mathrm{nM}$ primers, and $1.0 \mu \mathrm{g}$ of RNA per sample. The thermal cycling conditions were programmed as follows: preheating for 10 min at $95^{\circ} \mathrm{C}$, followed by 45 cycles of two-step PCR consisting of $15 \mathrm{~s}$ at $95^{\circ} \mathrm{C}$ and $1 \mathrm{~min}$ at $60^{\circ} \mathrm{C}$ (the extension temperature). The accumulation of PCR products was monitored through the increase in fluorescence. A standard curve was used for relative quantification.

\section{Immunohistochemistry analysis}

After completion of the experiments, each group of 4 mice was anesthetized with pentobarbital sodium $(42 \mathrm{mg} / \mathrm{kg}$, i.p.; Sigma Co., St. Lousis, MO) and fixed by perfusion using saline and cold $4 \%$ paraformaldehyde (PFA). Their brains were removed using the same experimental protocol used for qRT-PCR analysis and post-fixed in fresh 4\% PFA overnight at $4^{\circ} \mathrm{C}$, dehydrated in $30 \%$ sucrose at $4^{\circ} \mathrm{C}$ for $24 \sim 48$ $\mathrm{h}$, and stored at $-80^{\circ} \mathrm{C}$. Coronal sections $(15-\mu \mathrm{m}$ thick) were cut using a cryostatic microtome $\left(-25^{\circ} \mathrm{C}\right)$, and immunohistochemistry was subsequently performed. These tissue sections were post-fixed in $4 \% \mathrm{PFA}$ for $10 \mathrm{~min}$. The sections were incubated with the CART antibody (1:50) di- 
luted in TBS overnight at $4^{\circ} \mathrm{C}$ following a blocking step in diluted normal serum for $30 \mathrm{~min}$. After three washes with TBS-T, the sections were bound with a diluted biotinylated secondary antibody solution and the Vectastain ABC reagent. The sections were incubated in a diaminobenzidine (DAB) solution until the desired stain intensity developed. It was then counterstained by a hematoxylin. Finally, sections were dehydrated in ethanol, cleared in xylene, mounted with permount (Millipore Co., Bedford, MA, USA), and evaluated using light microscopy (Carl Zeiss Co., Jena, Germany). To determine the expression of CART, the stained cells were counted. The twelve coronal sections with four different animal brains in each group were analyzed. Four striatal regions, including the dorsolateral (DL) part of caudate putamen (CP), ventrolateral (VL) part of $\mathrm{CP}$, NAc shell, and NAc core in each section were selected. Cells at three randomly selected areas $(100 \times 100 \mu \mathrm{m})$ in each region were assessed. The immunoreactive cells by CART antibody were counted and expressed as percentage of stained cells. The quantity of CART-positive cells was expressed as the average number of reactive cells per high-power field.

\section{Western blot analysis}

WT and KO mice were respectively sacrificed by decapitation $22 \mathrm{~h}$ after the last administration of cocaine or saline. The striata, including the NAc, were extracted at the coronal level at ${ }^{+} 1.6$ and ${ }^{+} 1.0 \mathrm{~mm}$ from the bregma, according to the stereotaxic atlas [25]. The striata was dissected in ice-cold saline and homogenized in the protein extraction solution (Millipore Co., Bedford, MA, USA). The supernatant was collected and stored frozen $\left(-20^{\circ} \mathrm{C}\right)$. The protein concentration of the supernatant was determined using the Bradford method with bovine serum albumin as the standard. Equal amounts of the proteins were separated on a SDS/16\%-polyacrylamide gel and subsequently transferred to a polyvinylidene difluoride (PVDF) membrane. The membrane was blocked in $0.5 \%$ not-fat milk in TBS-T [10 mM Tris (pH 8.0) containing 0.05\% Tween-20], followed by three washes with TBS-T. The membranes were bound with specific antibodies using the SNAP id system (Millipore Co., Bedford, MA, USA). Anti-CART (1:67 dilution), anti-CREB (1:250 dilution), and anti-phospho-CREB (1:167 dilution) antibodies were used in this study. The membrane was incubated with the corresponding conjugated immunoglobulin G-horseradish peroxidase. The immunoreactivity was visualized following incubation with the ECLPlus chemiluminescent substrate (Roche Co., Mannheim, Germany). Chemiluminescence was detected using the Fusion-FX7 imaging system (Vilber Lourmat Co., Cedex, France). The bands were quantified using densitometry (OD) and Fusion CAPI analysis software.

\section{cAMP analysis}

WT and KO mice were respectively sacrificed by decapitation $22 \mathrm{~h}$ after the last administration of cocaine or saline. The striata, including the NAc, were extracted at the coronal level at ${ }^{+} 1.6$ and ${ }^{+} 1.0 \mathrm{~mm}$ from the bregma, according to the stereotaxic atlas [25]. The striata were dissected in ice-cold saline and homogenized in the protein extraction solution. The cAMP levels were determined using a competition enzyme-linked immunoassay (ELISA). The absorbance for this developed color was measured by the spectrofluorometer (BMG Co., Ortenberg, Germany) for emission at $450 \mathrm{~nm}$. Measurement of the absorbance using the cAMP standard allows us to calculate the absolute amount of cAMP in a sample of interest. The amount of tissue was $5.0 \mathrm{mg}$, and the results were expressed as nmol (nM) cAMP/mg tissue.

\section{$P K A$ radiometric analysis}

WT and KO mice were respectively sacrificed by decapitation $22 \mathrm{~h}$ after the last administration of the chemicals or saline. The striata, including the NAc, were extracted at the coronal level at ${ }^{+} 1.6$ and ${ }^{+} 1.0 \mathrm{~mm}$ from the bregma, according to the stereotaxic atlas [25]. The striata were dissected in ice-cold saline and homogenized in protein extraction solution. The PKA protein was purified from the total protein $(300 \mu \mathrm{g})$ by immunoprecipitation using the anti-PKA antibody. The PKA immunoprecipitate was dissolved in assay dilution buffer for radiometric analysis. Equal amounts of the PKA immunoprecipitate were added to incubation tubes containing $1.67 \mu \mathrm{M}$ cAMP, $0.08 \mathrm{mM}$ kemptide, $0.33 \mu \mathrm{M} \mathrm{PKC} / \mathrm{CaMK}$ inhibitor cocktail, and 1.67 $\mu \mathrm{Ci}$ of the $\left[\gamma{ }^{32 \mathrm{P}}\right] \mathrm{ATP} / \mathrm{magnesium} / \mathrm{ATP}$ cocktail brought to a total volume of $60 \mu \mathrm{l}$ with PBS. The complex solution was incubated with shaking at $30^{\circ} \mathrm{C}$ for $10 \mathrm{~min}$. A square piece of numbered P81 phosphocellulose paper was blotted with a $25-\mu 1$ aliquot and then washed with $0.75 \%$ phosphoric acid 3 times and with acetone once. The result was read in a Wallac 1450 Microbeta Trilux liquid scintillation counter (Cardinal Health Co., Dublin, OH, USA) and calculated by comparing the counts per minute (CPM) for PKA with the CPM for control samples that did not contain the enzyme. The results are expressed as pmol phosphate incorporated into Kemptide/min/ $\mu \mathrm{g}$ protein.

\section{Statistical analysis}

The results are presented as the mean \pm SEM. The significance of the effects was assessed between treatment groups by Student's $t$ test and within groups by one-way analysis of variance (ANOVA) followed by Dunnett's post

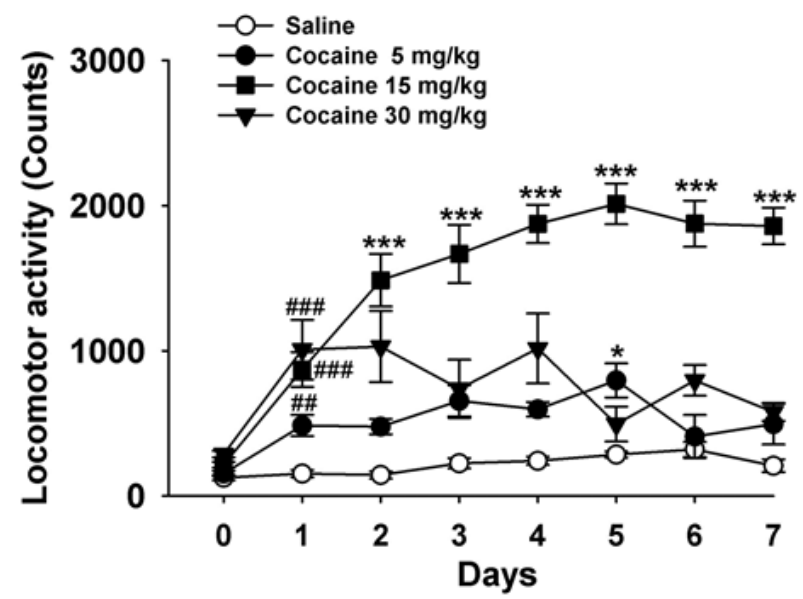

Fig. 1. Effects of cocaine $(5,15$ and $30 \mathrm{mg} / \mathrm{kg}$ ) on the locomotor activity of mice for 7 days. The data are given as the means \pm SEM of at least 8 mice. ${ }^{\#} \mathrm{p}<0.01$ and ${ }^{\# \#} \mathrm{p}<0.001$, compared with that of the saline group. ${ }^{*} \mathrm{p}<0.05,{ }^{* *} \mathrm{p}<0.01$ and ${ }^{* * *} \mathrm{p}<0.001$, compared with that of the cocaine group on the $1^{\text {st }}$ day. 
A

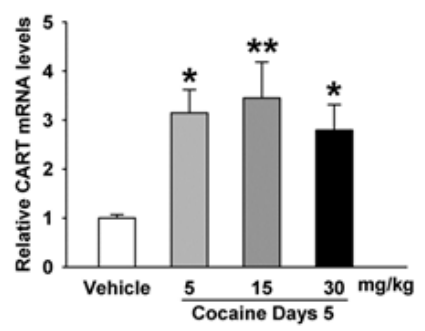

C

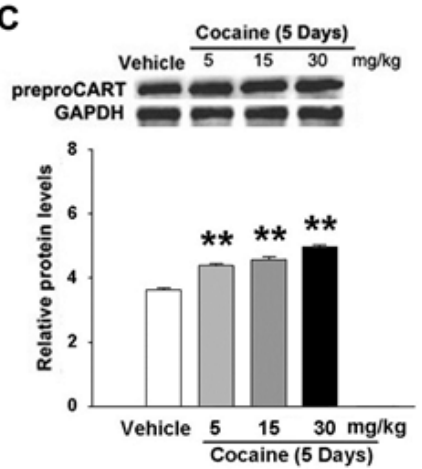

B

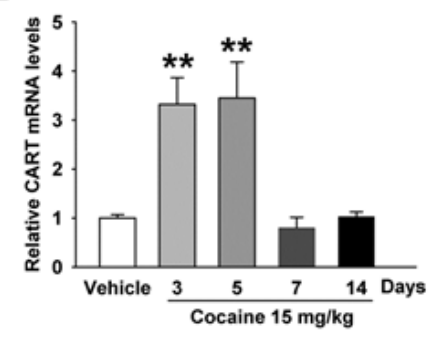

D

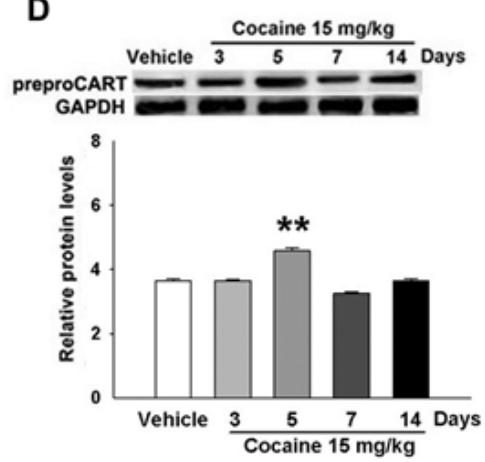

Fig. 2. Effects of cocaine on the levels of CART peptides mRNA in the striatum of mice. (A) Effects on the level of CART mRNA at different doses of cocaine $(5,15$ and $30 \mathrm{mg} / \mathrm{kg})$ on the $5^{\text {th }}$ day. (B) Effects on the level of CART mRNA at different time points $\left(3^{\text {rd }}\right.$, $5^{\text {th, }} 7^{\text {th }}$ and $14^{\text {th }}$ days) for the most effective dose of cocaine $(15 \mathrm{mg} / \mathrm{kg}$ ). (C) Effects on the level of CART peptides for different doses of cocaine (5, 15 and $30 \mathrm{mg} / \mathrm{kg}$ ). (D) Effects on the level of CART peptides at different time points $\left(3^{\text {rd }}, 5^{\text {th }}, 7^{\text {th }}\right.$ and $14^{\text {th }}$ days $)$ for the most effective dose of cocaine $(15 \mathrm{mg} / \mathrm{kg})$. A quantitative analysis was conducted by measuring the relative densitometry (OD) of the immunoreactive signal between preproCART and GAPDH. Data are given as the means \pm SEM of 4 mice. The total ninety six mice were used for the measurement of CART mRNA and protein levels. ${ }^{*} \mathrm{p}<0.05$ and ${ }^{* *} \mathrm{p}<0.01$, compared with that of the control (saline) group.

A

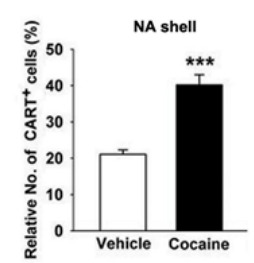

B

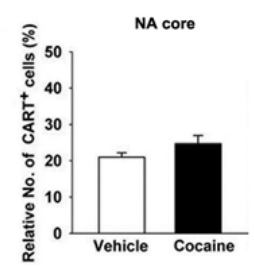

C

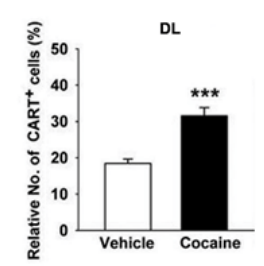

D

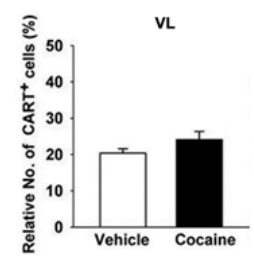

Fig. 3. Effects of cocaine on the $5^{\text {th }}$ day on the proportion of $\mathrm{CART}^{+}$ cells in the mouse striatum $(A \sim D)$. Plot of the proportion of striatial $\mathrm{CART}^{+}$cells through the NAc shell (A), DL part of CP (C), NAc core (B) and VL (D) part of CP immunolabeled for CART from mice treated with cocaine $(15 \mathrm{mg} / \mathrm{kg})$. Data are given as the means \pm SEM of 4 mice. The total eight mice were used. ${ }^{* * *} \mathrm{p}<0.001$, compared with that of the control (saline) group.

hoc test. The interactions between the $\mathrm{D}_{1} \mathrm{R}$ or $\mathrm{D}_{2} \mathrm{R}$ antagonists and drugs-to-saline and between the $\mathrm{D}_{1} \mathrm{R}$ - or $\mathrm{D}_{2} \mathrm{R}-\mathrm{KO}$ mice and drugs-to-saline were assessed by two-way ANOVA

respectively followed by Bonferroni's post hoc test. Statistical significance was defined as $\mathrm{p}<0.05$.

\section{RESULTS}

\section{Repeated cocaine induced behavioral sensitization in mice}

Repeated administrations of cocaine ( 5 and $15 \mathrm{mg} / \mathrm{kg}$ ) induced behavioral sensitization $(n=8 \sim 10, p<0.001$ and $p$ $<0.05$, Fig. 1), but not at $30 \mathrm{mg} / \mathrm{kg}$ used in this experiment. Cocaine-induced behavioral sensitization was initiated on the $2^{\text {nd }}$ day $[\mathrm{F}(3,34)=8.89, \mathrm{p}<0.001$, Fig. 1], peaked on the $5^{\text {th }}$ day $[\mathrm{F}(3,31)]=28.89, \mathrm{p}<0.001$, Fig. 1$)$ and continued to the $7^{\text {th }}$ day.

\section{Repeated cocaine increased the levels of CART mRNA and peptides in the mouse striatum}

In the qRT-PCR experiments, repeated cocaine (5, 15 and $30 \mathrm{mg} / \mathrm{kg}$ ) administration increased the level of CART mRNA by $3.1-, 3.5-$, and 2.8 -fold, respectively, on the $5^{\text {th }}$ day (Fig. 2A). Mice given $15 \mathrm{mg} / \mathrm{kg}$ of cocaine had significantly elevated the levels of CART mRNA on the $3^{\text {rd }}$ and $5^{\text {th }}$ days $(n=4, p<0.01$, Fig. $2 B)$, which peaked on the $3^{\text {rd }}$ day $(n=4, p<0.01$, Fig. $2 B)$, and returned to the control (saline, $\mathrm{n}=4$ ) levels on the $7^{\text {th }}$ day.

Western blot analysis revealed that cocaine increased the levels of the CART peptides in the striata in an inverted 
"U" manner. Cocaine significantly elevated the expression of CART peptides on the $5^{\text {th }}$ day $(\mathrm{n}=4, \mathrm{p}<0.01$, Fig. $2 \mathrm{C})$. A significant increase in levels of the CART peptides was observed on the $5^{\text {th }}$ day $(\mathrm{n}=4, \mathrm{p}<0.01$, Fig. 2D) after mice were given $15 \mathrm{mg} / \mathrm{kg}$ of cocaine when compared with the control (saline, $n=4$ ) group, but returned to the control levels on the $7^{\text {th }}$ and $14^{\text {th }}$ days.

\section{Distribution of $\mathrm{CART}^{+}$cells were found in the coca- ine-treated mice striata}

Within the NAc shell of the striata in mice treated with saline $(n=4), 21 \pm 2 \%$ of cells were $\mathrm{CART}^{+}$, whereas $40 \pm 5 \%$ of $\mathrm{CART}^{+}$were found in mice treated with cocaine (15 $\mathrm{mg} / \mathrm{kg}, \mathrm{n}=4)$ on the $5^{\text {th }}$ day (Fig. 3A). The proportion of $\mathrm{CART}^{+}$cells within DL part of CP in the cocaine-treated mice was $32 \pm 4 \%$ (Fig. 3C). These results indicated a higher proportion of $\mathrm{CART}^{+}$cells in the cocaine-treated mice were present within the NAc shell than DL part of CP. However, the proportion of $\mathrm{CART}^{+}$cells in the VL part of $\mathrm{CP}$ and NAc core was not significantly different in cocaine-treated mice compared with saline-treated mice (Fig. 3B).

\section{$D_{1} R$ and $D_{2} R$ antagonists inhibited cocaine-induced behavioral sensitization and CART peptides over-ex- pression}

Both SCH $23390\left(\mathrm{D}_{1} \mathrm{R}\right.$ antagonist, $\left.0.25 \mathrm{mg} / \mathrm{kg}\right)$ and raclopride $\left(\mathrm{D}_{2} \mathrm{R}\right.$ antagonist, $\left.0.4 \mathrm{mg} / \mathrm{kg}\right)$ inhibited behavioral sensitization induced by cocaine $(15 \mathrm{mg} / \mathrm{kg})$ on the $5^{\text {th }}$ day of treatment $\left(\mathrm{F}_{[4,41]}=25.51, \mathrm{p}<0.001, \mathrm{n}=8\right.$, Fig. $\left.4 \mathrm{~A}\right)$. Cocaine-induced behavioral sensitization was also significantly decreased by the concomitant administration of SCH 23390 and raclopride $(\mathrm{n}=8, \mathrm{p}<0.001$, Fig. $4 \mathrm{~A})$. Subsequently, each SCH 23390 and raclopride treatment inhibited CART peptides over-expression ( $=4, p<0.001$, Fig. $4 \mathrm{D})$, whereas concomittant administration of two antagonists inhibited CART peptides over-expression ( $\mathrm{n}=4, \mathrm{p}<0.001$, Fig. 4D), cAMP $(\mathrm{n}=4, \mathrm{p}<0.001$, Fig. 4B), and PKA activity $(\mathrm{n}=4, \mathrm{p}<0.01$ and $\mathrm{p}<0.001$, Fig. 4 C), and $p$ CREB $(\mathrm{n}=4, \mathrm{p}<0.01$ and $\mathrm{p}<0.001$, Fig. 4E) more than SCH 23390 and raclopride alone. It is suggested that cocaine-induced overexpression of CART peptides were directly mediated simultaneously by both $\mathrm{D}_{1} \mathrm{R}$ and $\mathrm{D}_{2} \mathrm{R}$-mediated signaling pathways. However, the level of CREB in the striata did not change significantly after
A

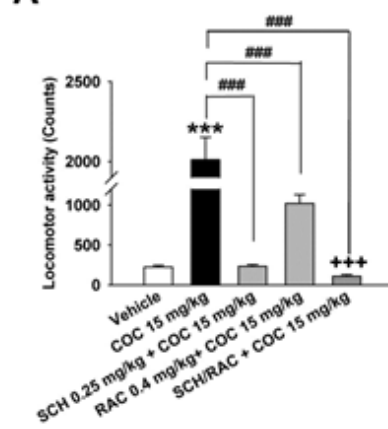

D

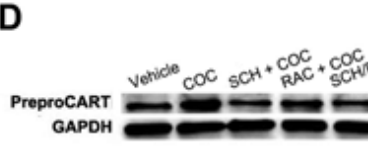

\section{E}
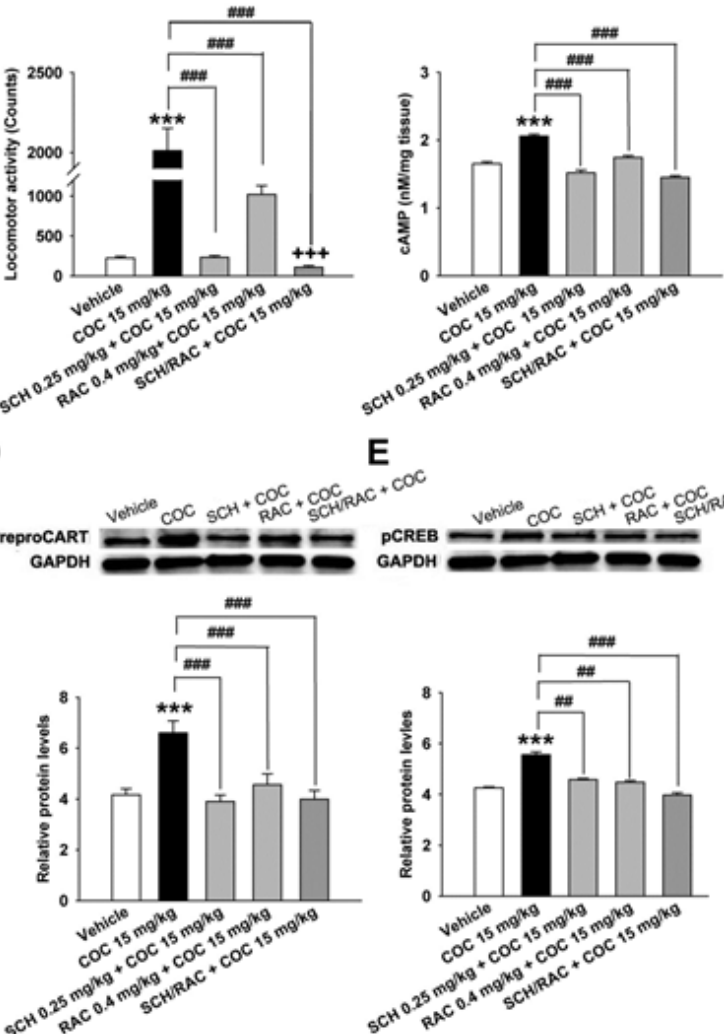

C

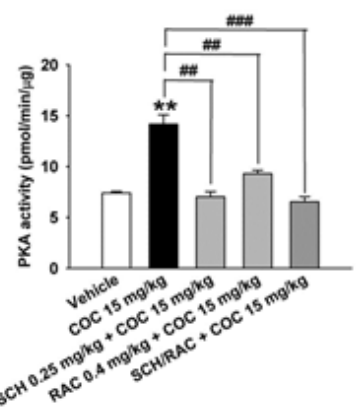

$\mathbf{F}$
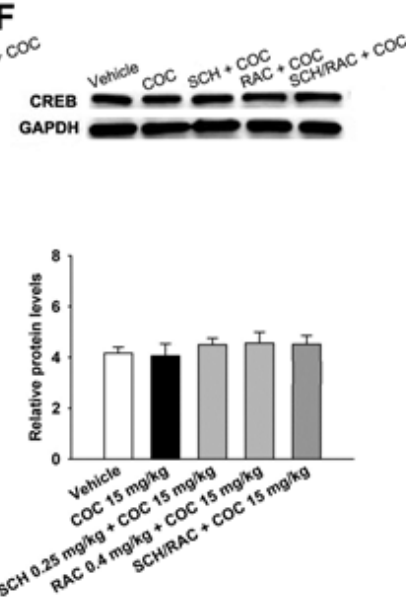

Fig. 4. Effects of SCH $23390(0.25 \mathrm{mg} / \mathrm{kg})$ and raclopride $(0.4 \mathrm{mg} / \mathrm{kg})$ on cocaine (15 mg/kg)-induced locomotor, CART expression, cAMP levels, PKA activity, and $p$ CREB levels in the mice striatum. (A) Cocaine was administered in mice one time per day for 5 days. The locomotor activity was measured using the tilting-type ambulometer. (B) The cAMP levels were measured using the competition enzyme-linked immunoassay (ELISA). (C) After PKA was purified by immunoprecipitation, the PKA activity was measured using a radiometric assay. The CART levels (D), CREB phosphorylation (E), and (F) CREB levels were observed using western blotting. A quantitative analysis was conducted by measuring the relative OD of the immunoreactive signal for preproCART, $p$ CREB, CREB, and GAPDH. Data represent the means \pm SEM of 4 mice. The total twenty mice were used. ${ }^{* *} \mathrm{p}<0.01$ and ${ }^{* * *} \mathrm{p}<0.001$, compared with that of the control (saline) group; ${ }^{\#} \mathrm{p}<0.01$ and ${ }^{\#} \mathrm{p}<0.001$, compared with that of the cocaine group; ${ }^{+} \mathrm{p}<0.001$ and ${ }^{+++} \mathrm{p}<0.001$, compared with that of the raclopride group. 
administration of cocaine alone or in combination with $\mathrm{SCH}$ 23390 and raclopride, and it appeared to be almost the same as the control level $(n=4$, Fig. $4 F)$.

\section{Cocaine-induced behavioral sensitization and CART peptides expressions were found in $D_{1} R$ - and $D_{2} R-K O$ mice}

The repeated cocaine administration induced BS on the $5^{\text {th }}$ day compared with the control (saline, $n=4$ ) group in $\mathrm{D}_{1} \mathrm{R}-\left(\mathrm{F}_{[2,11]}=27.24, \mathrm{p}<0.001\right.$, Fig. $\left.5 \mathrm{~A}\right)$ and $\mathrm{D}_{2} \mathrm{R}-\mathrm{KO}$ mice $\left(F_{[2,8]}=15.97, p<0.01\right.$, Fig. $\left.6 A\right)$. Furthermore, repeated administration of cocaine increased the CART peptide levels in the $\mathrm{D}_{1} \mathrm{R}-\mathrm{KO}$ (cocaine, $\mathrm{p}<0.001 ; \mathrm{n}=5$, Fig. $5 \mathrm{D}$ ) and $\mathrm{D}_{2} \mathrm{R}-\mathrm{KO}$ mice (cocaine, $\mathrm{p}<0.05 ; \mathrm{n}=4$, Fig. $6 \mathrm{D}$ ) when compared with the control (saline, $n=4$ ) group. Accordingly, the increases in cAMP level, PKA activity, and $p$ CREB levels after cocaine treatment were observed in the $\mathrm{D}_{1} \mathrm{R}-\mathrm{KO}$ (cAMP: $\mathrm{p}<0.01$, $\mathrm{n}=5$, Fig. 5B; PKA: $\mathrm{p}<0.001, \mathrm{n}=5$, Fig. 5C; $p$ CREB: $\mathrm{p}<0.001$, $\mathrm{n}=5$, Fig. 5E) and $\mathrm{D}_{2} \mathrm{R}-\mathrm{KO}$ mice (cAMP: $\mathrm{p}<0.05, \mathrm{n}=4$, Fig. 6B; PKA: $\mathrm{p}<0.01, \mathrm{n}=4$, Fig. $6 \mathrm{C} ; \mathrm{pCREB}: \mathrm{p}<0.05, \mathrm{n}=4$, Fig. $6 \mathrm{E})$.

Cocaine administration did not significantly increase locomotor activity (saline, $\mathrm{p}<0.05, \mathrm{n}=4$; cocaine, $\mathrm{p}<0.01$, $\mathrm{n}=5$; Fig. $5 \mathrm{~A})$ in $\mathrm{D}_{1} \mathrm{R}-\mathrm{KO}$ and $\mathrm{D}_{2} \mathrm{R}-\mathrm{KO}$ mice $(\mathrm{n}=3 \sim 4$, Fig. $6 \mathrm{~A})$. However, CART expression was decreased in cocaine treated $\mathrm{D}_{1} \mathrm{R}-\mathrm{KO}$ mice (saline, $\mathrm{p}<0.01, \mathrm{n}=4$; cocaine, $\mathrm{p}<0.05, \mathrm{n}=5$; Fig. $5 \mathrm{D})$. cAMP/PKA/ $p$ CREB signaling pathways were re- duced in $\mathrm{D}_{1} \mathrm{R}-\mathrm{KO}$ mice (cAMP: $\mathrm{p}<0.001, \mathrm{n}=4 \sim 5$, Fig. $5 \mathrm{~B}$; PKA: $\mathrm{p}<0.01, \mathrm{n}=4 \sim 5$, Fig. 5C; $p$ CREB: $\mathrm{p}<0.05, \mathrm{n}=4 \sim 5$, Fig. $5 \mathrm{E})$ on the $5^{\text {th }}$ day. In contrast, CART peptides were increased in cocaine treated $\mathrm{D}_{2} \mathrm{R}-\mathrm{KO}$ mice $(\mathrm{p}<0.05, \mathrm{n}=4$, Fig. 6D) and $p$ CREB $(\mathrm{p}<0.05, \mathrm{n}=4$, Fig. 6E). However, cAMP levels and PKA activity did not increase significantly increase repeated administrations of saline or cocaine $(n=3 \sim$ 5, Fig. 5F and Fig. 6F).

\section{DISCUSSION}

It has been well known that repeated intermittent administration of cocaine produces progressive enhancement in locomotor activity, a phenomenon known as behavioral sensitization. The close correlations between behavioral sensitization and the overexpression of CART peptides by cocaine were suggested. After peaking on the $5^{\text {th }}$ day, both behavioral sensitization and overexpression of CART proteins gradually decreased on the $7^{\text {th }}$ day $[27,28]$. It was also confirmed in the present study. Repeated administration of cocaine started to simultaneously induce behavioral sensitization and CART over-expression on the $3^{\text {rd }}$ day. These results are consistent with the previous findings that the level of CART peptides elevates at the onset, peaks during the process, and returns to biophysiological levels at the end in response to various repeated stimuli [29-31]. CART peptides are peptidergic neurotransmitter that is expressed
A

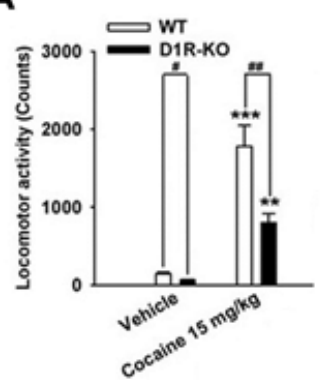

D

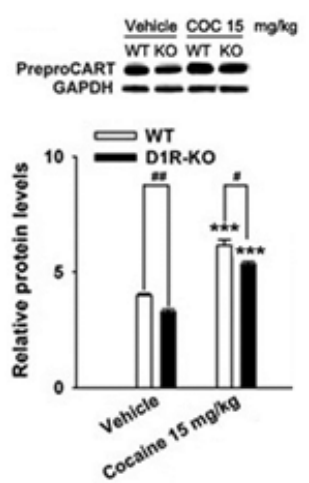

B

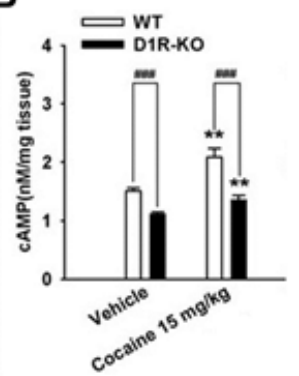

E

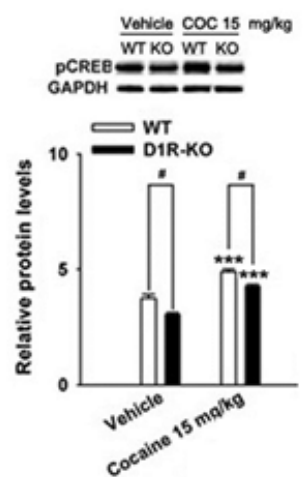

C

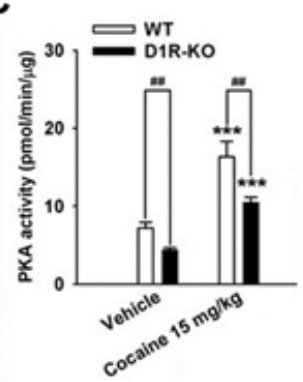

$\mathbf{F}$

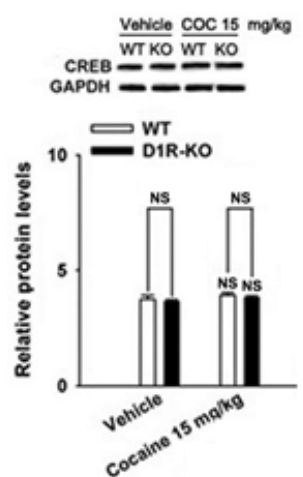

Fig. 5. Effects in WT mice and $D_{1} R-K O$ mice treated with cocaine $\left(15 \mathrm{mg} / \mathrm{kg}\right.$ ) on the $5^{\text {th }}$ day on locomotor activity (A), cAMP levels (B), PKA activity (C), CART levels (D), pCREB levels (E), CREB levels (F). A quantitative analysis was conducted by measuring the relative OD of the immunoreactive signal for preproCART, pCREB, CREB, and GAPDH. Data are given as the means \pm SEM of $4 \sim 5$ mice. The total twenty mice were used. ${ }^{* *} \mathrm{p}<0.01$ and ${ }^{* * *} \mathrm{p}<0.001$, compared with that of the control (saline) group; ${ }^{\#} \mathrm{p}<0.05,{ }^{\#} \mathrm{p}<0.01$ and ${ }^{\# \# \#} \mathrm{p}<0.001$, compared with that of the WT or KO mice group. 
in regions of the brain regions involved in critical biological processes such as feeding, stress, and in areas associated with drug reward and abuse, including the dopamine-rich NAc, which can be considered part of the basal ganglia [32]. Both CART over-expression and behavioral sensitization are closely related to DR. The DR-mediated cAMP/PKA signaling pathway activation underlies the over-expression of CART peptides induced by cocaine in the striatum [16,33]. Dopaminergic neurons in the VTA and substantia nigra (SN) receive a CART input. There is also sufficient evidence for CART systems being affected by dopamine. CART was observed to particularly regulated by dopamine in the NAc, at least partly by $\mathrm{D}_{3} \mathrm{R}$ [18]. However, it remains unclear how CART peptides over-expression is mediated via $D_{1} R$ and $D_{2} R$ in the development of cocaine-induced behavioral sensitization.

From these experiments, both $\mathrm{D}_{1} \mathrm{R}$ - and $\mathrm{D}_{2} \mathrm{R}$-antagonists blocked cocaine-induced behavioral sensitization. Moreover, the combined treatment of $\mathrm{D}_{1} \mathrm{R}$ and $\mathrm{D}_{2} \mathrm{R}$ antagonists produced less locomotor activity than $\mathrm{D}_{1} \mathrm{R}$ and $\mathrm{D}_{2} \mathrm{R}$ antagonists alone. In terms of mediation of reward induced by cocaine, the stimulation of $D_{1} R$ results in fast neuronal activation, and the stimulation of $\mathrm{D}_{2} \mathrm{R}$ results in progressive neuronal deactivation [7]. The weaker behavioral sensitization by cocaine was developed in the $\mathrm{D}_{1} \mathrm{R}$ - and $\mathrm{D}_{2} \mathrm{R}-\mathrm{KO}$ mice compared to the WT mice, although repeated cocaine administration still induced behavioral sensitization in both $\mathrm{D}_{1} \mathrm{R}$ and $\mathrm{D}_{2} \mathrm{R}-\mathrm{KO}$ mice. Behavioral effects of psychostimulants were also reduced in the mutant CART KO mice [34].
Co-administration of CART peptides with $D_{1} R$ and $D_{2} R$ agonists into the NAc reduces locomotor activity, whereas co-administration of CART peptides enhances the increase in locomotor activity induced by $\mathrm{D}_{1} \mathrm{R}$ agonists [16]. Both behavioral sensitization and CART peptides may be closely correlated with simultaneous $\mathrm{D}_{1} \mathrm{R}$ and $\mathrm{D}_{2} \mathrm{R}$ activation (is that correct?). The minimal estimated proportion of neurons expressing $\mathrm{D}_{1} \mathrm{R}$ is $64 \%$ in the NAc shell, and $57 \%$ and $59 \%$ in the CP and the NAc core, respectively, although various regions in the striatum comprise a higher percentage of neurons expressing $D_{1} R$ than $D_{2} R$ according to previous reports [6]. We found that there are also differences in the proportion of $\mathrm{CART}^{+}$cells in various regions of the striatum. The proportion of $\mathrm{CART}^{+}$cells are significantly increased by cocaine within the NAc shell and the CP-DL, but not within the NAc core and CP-VL part. CART cells in the NAc of rats is co-localized with substance $\mathrm{P}$, dynorphin, and $\mathrm{D}_{1} \mathrm{R}$ [32]. It has been suggested that behavioral sensitization and the expression of CART peptides is predominantly mediated by $\mathrm{D}_{1} \mathrm{R}$ than $\mathrm{D}_{2} \mathrm{R}$.

Psychostimulants-induced over-expression of CART peptides and phosphorylation of ERK and CREB was mediated by $\mathrm{D}_{1} \mathrm{R}$ which stimulated the cAMP/PKA signaling in striatonigral (direct pathway) neurons [6,35]. Because the over-expression of CART peptides after repeated cocaine treatment is shown to be activated by cAMP, PKA and $p$ CREB [36], our present study suggest that inhibiting overexpression of CART peptides could be responsible for attenuation of cAMP, PKA and, $p$ CREB levels in mice lacking $\mathrm{D}_{1} \mathrm{R}$ using a phar-
A

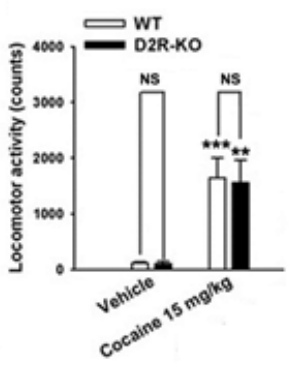

D

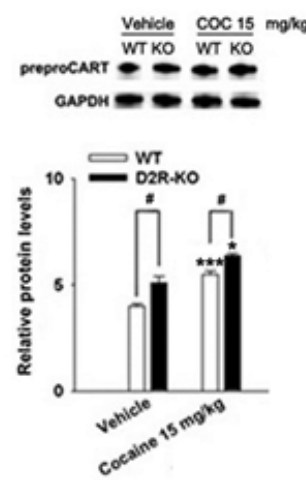

B

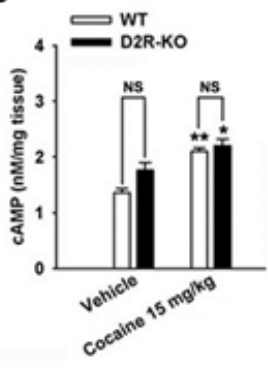

$\mathbf{E}$

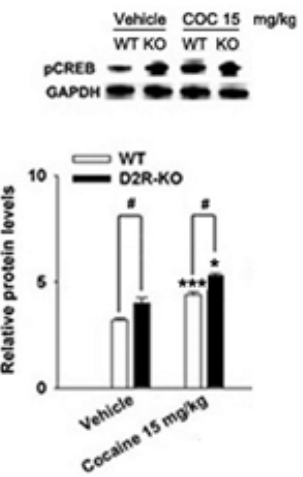

C

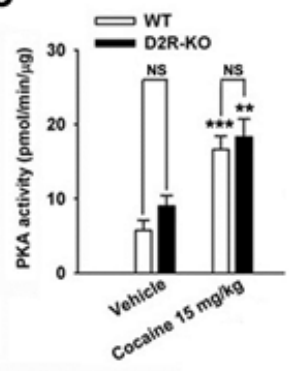

$\mathbf{F}$

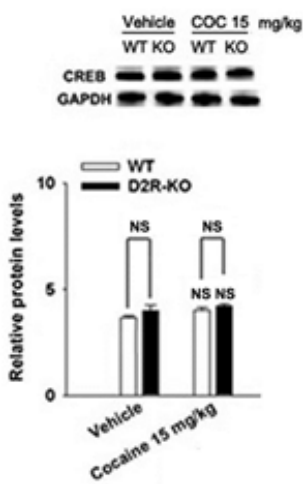

Fig. 6. Effects in WT mice and $\mathrm{D}_{2} \mathrm{R}-\mathrm{KO}$ mice treated with cocaine $(15 \mathrm{mg} / \mathrm{kg})$ on the $5^{\text {th }}$ day on locomotor activity (A), cAMP levels (B), PKA activity (C), CART levels (D), pCREB levels (E), CREB levels (F). Quantitative analysis was conducted by measuring the relative $\mathrm{OD}$ of the immunoreactive signal for prepro CART, $p$ CREB, CREB, and GAPDH. Data represent the means \pm SEM of $3 \sim 4$ mice. The total sixteen mice were used. ${ }^{*} \mathrm{p}<0.05,{ }^{* *} \mathrm{p}<0.01$ and ${ }^{* * *} \mathrm{p}<0.001$, compared with that of the control (saline) group; ${ }^{*} \mathrm{p}<0.05$, compared with that of the KO or WT mice. 
macological and genetic approach. In the present study, though SCH 23390 and raclopride decreased the level of CART peptides over-expression induced by cocaine, respectively, the degree of decrease in CART peptides over-expression induced by combinated injection of two drugs was not greater than the injection of a single drug. Similar possible explanations for this lack of an additive effect are that the $D_{1} R$, but not the $D_{2} R$, is a critical regulator for gene expressions during the development of BS. We agree with the previous studies that $\mathrm{D}_{2} \mathrm{R}$ antagonists are less effective in inhibiting the psychostimulants-induced $p$ CREB than $\mathrm{D}_{1} \mathrm{R}$ antagonists [37,38]. This possibility is also supported by Bertran-Gonzalez et al. [6] who reported that early ERK activation in mice treated with repeated cocaine treatments remained restricted to $D_{1} R$-expressing neurons in the $D L$ striatum. Of course, the involvement of the $\mathrm{D}_{2} \mathrm{R}$ does not preclude the contribution of CART over-expression induced by cocaine. Raclopride decreased the cocaine-induced CART over-expression, which is consistent with previous findings that raclopride inhibited the over-expression of CART peptides by ethanol in the rat NAc [19]. Valjent et al. demonstrated that raclopride partially decreased cocaine-induced ERK activation in the DL striatum of mice [35]. Thus, gene expression is mediated, in part, by activation of $\mathrm{D}_{2} \mathrm{R}$ in striatopallidal neurons. Interestingly, CART expression after repeated cocaine treatment in $\mathrm{D}_{2} \mathrm{R}-\mathrm{KO}$ mice was increased, compared to WT mice which in contrast appeared to lose their IEG activation response to cocaine treatment [39]. The underlying mechanism of the higher sensitivity of CART peptides to cocaine in $\mathrm{D}_{2} \mathrm{R}-\mathrm{KO}$ mice is presently unclear. But, it may correlate with increased stimulation of $D_{1} R$ due to leading to the increase of $D A$ release in $\mathrm{D}_{2} \mathrm{R}-\mathrm{KO}$ mice, which may delete presynaptic autoreceptors [40]. It may also depend on the activation of this gene by the release of pituitary hormone in the absence of $D_{2} R$ [41,42].

In summary, $\mathrm{D}_{1} \mathrm{R}$ - and $\mathrm{D}_{2} \mathrm{R}$-mediated signal pathways simultaneously modulated the expression of CART mRNA and peptides during the development of behavioral sensitization after repeated cocaine administration, which is consistent with previous findings $[9,18,36]$. $\mathrm{CART}^{+}$cells in the NAc shell and DL caudate putamen were significantly increased in the cocaine-treated mouse. $\mathrm{D}_{1} \mathrm{R}$ - and $\mathrm{D}_{2} \mathrm{R}$-antagonists blocked CART over-expression induced by cocaine. Cocaine induced CART over-expression was weaker in the $\mathrm{D}_{1} \mathrm{R}-\mathrm{KO}$ mice and stronger in the $\mathrm{D}_{2} \mathrm{R}-\mathrm{KO}$ mice when compared to the WT mice. These results suggest that CART over-expression induced by repeated administration of cocaine could be more predominantly involved in $D_{1} R$.

\section{ACKNOWLEDGEMENTS}

This work was supported by the National Research Foundation of Korea (NRF) grant funded by the Korea government (MEST) (MRC, 2011-0028213).

\section{REFERENCES}

1. McGregor IS, Atrens DM, Jackson DM. Cocaine facilitation of prefrontal cortex self-stimulation: a microstructural and pharmacological analysis. Psychopharmacology (Berl). 1992;106:239-247.

2. Kuribara H. Modification of cocaine sensitization by dopamine $\mathrm{D} 1$ and D2 receptor antagonists in terms of ambulation in mice.
Pharmacol Biochem Behav. 1995;51:799-805.

3. Nazarian A, Russo SJ, Festa ED, Kraish M, Quinones-Jenab $\mathrm{V}$. The role of D1 and D2 receptors in the cocaine conditioned place preference of male and female rats. Brain Res Bull. 2004;63:295-299.

4. Woolverton WL, Ranaldi R. Comparison of the reinforcing efficacy of two dopamine D2-like receptor agonists in rhesus monkeys using a progressive-ratio schedule of reinforcement. Pharmacol Biochem Behav. 2002;72:803-809.

5. Singh VP, Singh N, Jaggi AS. A review on renal toxicity profile of common abusive drugs. Korean J Physiol Pharmacol. 2013;17: 347-357.

6. Bertran-Gonzalez J, Bosch C, Maroteaux M, Matamales M, HervéD, Valjent E, Girault JA. Opposing patterns of signaling activation in dopamine D1 and D2 receptor-expressing striatal neurons in response to cocaine and haloperidol. $J$ Neurosci. 2008;28:5671-5685

7. Luo Z, Volkow ND, Heintz N, Pan Y, Du C. Acute cocaine induces fast activation of D1 receptor and progressive deactivation of D2 receptor striatal neurons: in vivo optical microprobe $\left[\mathrm{Ca}^{2+}\right]_{\mathrm{i}}$ imaging. J Neurosci. 2011;31:13180-13190.

8. Gao J, Li Y, Zhu N, Brimijoin S, Sui N. Roles of dopaminergic innervation of nucleus accumbens shell and dorsolateral caudate- putamen in cue-induced morphine seeking after prolonged abstinence and the underlying D1- and D2-like receptor mechanisms in rats. $J$ Psychopharmacol. 2013;27:181-191.

9. Capper-Loup C, Canales JJ, Kadaba N, Graybiel AM. Concurrent activation of dopamine D1 and D2 receptors is required to evoke neural and behavioral phenotypes of cocaine sensitization. $J$ Neurosci. 2002;22:6218-6227.

10. Drago J, Gerfen CR, Westphal H, Steiner H. D1 dopamine receptor-deficient mouse: cocaine-induced regulation of immediateearly gene and substance $\mathrm{P}$ expression in the striatum. Neuroscience. 1996;74:813-823.

11. Kim S, Shin JK, Yoon HS, Kim JH. Blockade of ERK Phosphorylation in the Nucleus Accumbens Inhibits the Expression of Cocaine-induced Behavioral Sensitization in Rats. Korean $J$ Physiol Pharmacol. 2011;15:389-395.

12. Chausmer AL, Katz JL. The role of D2-like dopamine receptors in the locomotor stimulant effects of cocaine in mice. Psychopharmacology (Berl). 2001;155:69-77.

13. Jaworski JN, Jones DC. The role of CART in the reward/ reinforcing properties of psychostimulants. Peptides. 2006;27:19932004.

14. Yoo SB, Lee S, Lee JY, Kim BT, Lee JH, Jahng JW. cAMP/PKA agonist restores the fasting-induced down-regulation of nNOS expression in the paraventricular nucleus. Korean $J$ Physiol Pharmacol. 2012;16:333-337.

15. Douglass J, McKinzie AA, Couceyro P. PCR differential display identifies a rat brain mRNA that is transcriptionally regulated by cocaine and amphetamine. J Neurosci. 1995;15:2471-2481.

16. Moffett MC, Song J, Kuhar MJ. CART peptide inhibits locomotor activity induced by simultaneous stimulation of D1 and D2 receptors, but not by stimulation of individual dopamine receptors. Synapse. 2011;65:1-7.

17. Lee S, Kim Y, Li E, Park S. Ghrelin protects spinal cord motoneurons against chronic glutamate excitotoxicity by inhibiting microglial activation. Korean J Physiol Pharmacol. 2012;16:43-48.

18. Hunter RG, Jones D, Vicentic A, Hue G, Rye D, Kuhar MJ. Regulation of CART mRNA in the rat nucleus accumbens via D3 dopamine receptors. Neuropharmacology. 2006;50:858-864.

19. Salinas A, Wilde JD, Maldve RE. Ethanol enhancement of cocaineand amphetamine-regulated transcript mRNA and peptide expression in the nucleus accumbens. J Neurochem. 2006;97:408-415.

20. Jones DC, Kuhar MJ. Cocaine-amphetamine-regulated transcript expression in the rat nucleus accumbens is regulated by adenylyl cyclase and the cyclic adenosine 5'-monophosphate/protein kinase a second messenger system. J Pharmacol Exp Ther. 2006;317:454-461.

21. Jones DC, Kuhar MJ. CART receptor binding in primary cell cultures of the rat nucleus accumbens. Synapse. 2008;62:122-127.

22. Lakatos A, Dominguez G,Kuhar MJ. CART promoter CRE site binds phosphorylated CREB. Brain Res Mol Brain Res. 
2002;104:81-85.

23. Tadokoro S, Kuribara H. Reverse tolerance to the ambulation-increasing effect of methamphetamine in mice as an animal model of amphetamine-psychosis. Psychopharmacol Bull. 1986;22:757-762.

24. Hu Z, Park KS, Han JY, Jang CG, Oh S, Kim HC , Yang CH, Kim EJ, Oh KW. Markers in morphine- and cocaine-addicted animals. Biomol Ther. 2011;19:45-51.

25. Franklin KB, Paxinos G. The mouse brain in stereotaxic coordinates. San Diego: Academic Press; 1997.

26. Tanegashima K, Okamoto S, Nakayama Y, Taya C, Shitara H, Ishii R, Yonekawa H, MinokoshiY, Hara T. CXCL14 deficiency in mice attenuates obesity and inhibits feeding behavior in a novel environment. PLoS One. 2010;5:e10321.

27. Morio A, Ujike H, Nomura A, Tanaka Y, Morita Y, Otani K, Kishimoto M, Harano M, Inada T, Komiyama T, Yamada M, Sekine Y, Iwata N, Iyo M, Sora I, Ozaki N, Kuroda S. No association between CART (cocaine- and amphetamine-regulated transcript) gene and methamphetamine dependence. Ann NY Acad Sci. 2006;1074:411-417.

28. Marie-Claire C, Laurendeau I, Canestrelli C, Courtin C, Vidaud M, Roques B, Noble F. Fos but not Cart (cocaine and amphetamine regulated transcript) is overexpressed by several drugs of abuse: a comparative study using real-time quantitative polymerase chain reaction in rat brain. Neurosci Lett. 2003;345:77-80.

29. Roh MS, Cui FJ, Ahn YM, Kang UG. Up-regulation of cocaine- and amphetamine-regulated transcript (CART) in the rat nucleus accumbens after repeated electroconvulsive shock. Neurosci Res. 2009;65:210-213.

30. Germano CM, de Castro M, Rorato R, Laguna MT, AntunesRodrigues J, Elias CF, Elias LL. Time course effects of adrenalectomy and food intake on cocaine- and amphetamine-regulated transcript expression in the hypothalamus. Brain Res. 2007;1166:55-64.

31. Jang HS, Kim JY, Kim SH, Lee MG. Role of dopamine receptors on electroencephalographic changes produced by repetitive apomorphine treatments in rats. Korean J Physiol Pharmacol. 2009;13:147-151.

32. Hubert GW, Kuhar MJ. Colocalization of CART peptide with prodynorphin and dopamine D1 receptors in the rat nucleus accumbens. Neuropeptides. 2006;40:409-415.
33. Jaworski JN, Vicentic A, Hunter RG, Kimmel HL, Kuhar MJ. CART peptides are modulators of mesolimbic dopamine and psychostimulants. Life Sci. 2003;73:741-747.

34. Couceyro PR, Evans C, McKinzie A, Mitchell D, Dube M, Hagshenas L, White FJ, Douglass J, Richards WG, Bannon AW. Cocaine- and amphetamine-regulated transcript (CART) peptides modulate the locomotor and motivational properties of psychostimulants. J Pharmacol Exp Ther. 2005;315:10911100.

35. Valjent E, Corvol JC, Pages C, Besson MJ, Maldonado R, Caboche J. Involvement of the extracellular signal-regulated kinase cascade for cocaine-rewarding properties. $J$ Neurosci. 2000;20:8701-8709

36. Rogge GA, Jones DC, Green T, Nestler E, Kuhar MJ. Regulation of CART peptide expression by CREB in the rat nucleus accumbens in vivo. Brain Res. 2009;1251:42-52.

37. Shi X, McGinty JF. D1 and D2 dopamine receptors differentially mediate the activation of phosphoproteins in the striatum of amphetamine-sensitized rats. Psychopharmacology (Berl). 2011;214:653-663.

38. Guan X, Tao J, Li S. Dopamine D1 receptor, but not dopamine D2 receptor, is a critical regulator for acute cocaine-enhanced gene expression. Neurol Res. 2009;31:17-22.

39. Welter M, Vallone D, Samad TA, Meziane H, Usiello A, Borrelli E. Absence of dopamine D2 receptors unmasks an inhibitory control over the brain circuitries activated by cocaine. Proc Natl Acad Sci U S A. 2007;104:6840-6845.

40. Rouge-Pont F, Usiello A, Benoit-Marand M, Gonon F, Piazza PV, Borrelli E. Changes in extracellular dopamine induced by morphine and cocaine: crucial control by D2 receptors. $J$ Neurosci. 2002;22:3293-3301.

41. Kelly MA, Rubinstein M, Asa SL, Zhang G, Saez C, Bunzow JR, Allen RG, Hnasko R, Ben-Jonathan N, Grandy DK, Low MJ. Pituitary lactotroph hyperplasia and chronic hyperprolactinemia in dopamine D2receptor-deficient mice. Neuron. 1997;19:103-113.

42. Fekete C, Lechan RM. Neuroendocrine implications for the association between cocaine- and amphetamine regulated transcript (CART) and hypophysiotropic thyrotropin-releasing hormone (TRH). Peptides. 2006;27:2012-2018. 